\title{
Mophometric Description of Gullies Developing on Coastal Plain Formations around Yewa South and Ipokia in Ogun State South-West Nigeria
}

\author{
F. O. Ogundele ${ }^{1}$, S. G. Odewumi ${ }^{1} \&$ Bello Ganniy ${ }^{1}$ \\ ${ }^{1}$ Department of Geography, Lagos State University, P.M.B. 1087, Apapa, Lagos, Nigeria \\ Correspondence: F. O. Ogundele, Department of Geography, Lagos State University, P.M.B. 1087, Apapa, \\ Lagos, Nigeria. Tel: 234-803-313-4404. E-mail: kunleogun@yahoo.co.uk
}

Received: August 27, 2012 Accepted: February 9, 2013 Online Published: February 27, 2013

doi:10.5539/jgg.v5n1p126 URL: http://dx.doi.org/10.5539/jgg.v5n1p126

\begin{abstract}
This study attempts to document morphometric parameters of some selected gullies in Owode, Ajilete, Oke-Odan and Idiroko areas of Yewa South and Ipokia Local Government Area (L.G.A) of Ogun State, Nigeria. Gully morphometric parameters and their interrelationships were examined in the coastal plain formation area of Ogun State. A total of thirty-two (32) gullies were sampled and the measurements of vital gullies parameters were taken in the field. These included; length (distance from Gully head), Gully depth, bed-width, and shoulder-width and slope angle. Others were shoulder-width/bed-width ratio, shoulder-width/depth ratio and cross sectional area were derived as the product of depth and width.

Descriptive statistical analysis was used to define the general morphometric characteristics of the sampled gullies. The mean, standard deviation, variance, coefficient of variation were determined for further works. The Pearson's product moment correlation was used to explore the difference between the mean values of the parameters. The analysis of the correlation matrix computed reveals that $65 \%$ of the correlation coefficient have relationships that are significant at 0.05 significance level while about $25 \%$ of the correlation coefficients have relationships that are not significant at all. Only $10 \%$ were found to be at the 0.01 level of significance.

The result of the analyses shows that these gullies are simple in plan with more or less direct courses. In all, some has broad U-shaped form while others have V-shaped form. In the study, most of the correlation coefficient was strongly correlated.

In conclusion, the differences observed in the study are believed to be attributable, to a large extent, to variation in soil texture, micro-climate, farm operation, vegetation cover and some other cultural practices in some of the places where these gullies are currently developing.
\end{abstract}

Keywords: gully, morphometric characteristics, environment, geology, erosion, soils

\section{Background to the Study}

Soil erosion is the process of detachment and transportation of soil materials either by water, winds and ice. Gully erosion is one of the several types that commences with the removal of the vegetation cover and the exposure of the surface to heavy rains and strong wind. Gullies consists of an open, incised and unstable channel generally more than $30 \mathrm{~cm}$ deep. However an established, but established gully system can be over 5 meter deep and so over considerable horizontal distance. It occurs where surface water flow has been trapped in a small concentrated stream, and begins to erode the channels of the ground surface. It is mainly created by running water eroding sharply into the top soil, typical of hill side; gullies resemble large ditches or small valleys, but are metres to tens of metres in depth and width. When the gully formation is in process the water flow rate can be substantial, which causes the significant deep cutting action beyond the top soil into the subsurface and regolith zone. Where the soils is loose and friable, or where sections are deeply weathered, gullies progress very fast and deepening may exceed widening by a ratio of 1 to 4 .

Soil erosion has been recognized as one of the major problems restricting agriculture worldwide, its extent and impact on human welfare and global environment are increasing at alarming rate. Gully resulting from accelerated soil erosion has been an issue of growing concern not only in Nigeria but in many parts of the world. 
They are known to develop by several processes which may occur singly or at the same time. The works of Areola (1990), Ofomata (1965, 1973 and 1978.), Jeje (1978, 1982 and 1991), and Ologe (1972, 1974 and 1988) in various parts of Nigeria have shown how gullies processes are sustained in various ecological zones of Nigeria.

Yewa and Ipokia are agricultural towns located on the sandy plains of south west Ogun State. The two towns are of peculiar importance as $75 \%$ of the inhabitants rely on agriculture as means of livelihood. The fertile land that has been supportive of farming is now under severe threat of gullies, both ephemeral and permanent ones. Some have also developed so rapidly as to threaten homes and roads. It is therefore necessary to embark on a systematic study of the gullies in this area in order to gain better insight of the nature of the gullies and certainly to serve as input to any solution that may be proffered towards solving the problem down the line. This will require that we study the gully morphology, inter-relationships and variations of gully parameters in relations to both causative and deterministic factors in coastal plains formations especially in the chosen geographical areas.

On the policy and action fronts for government there is the need to examine and document the gullies in the area in order for us to analyze the morphometric characteristics of the gullies with a view to find the best and lasting solution to the menace. The knowledge of the gully system will help the government to fashion out environmental management and control strategies to combat further development of the gully in question in the area and elsewhere. The aim of the study therefore is to describe and examine gully morphology, inter relationship and variation of parameters in relation to causative and deterministic factor in coastal plain formation.

\section{Description of Study Location}

The study area is located in Ogun State between latitudes $6.2^{\circ} \mathrm{N}$ and $7.8^{\circ} \mathrm{N}$ and longitudes $3.0^{\circ} \mathrm{E}$ and $5.0^{\circ} \mathrm{E}$. The two local government areas involved are; Yewa South and Ipokia under which the study locations are situated. The locations are no more than $32 \mathrm{kms}$ apart. Owode and Ajilete are on a linear depression towards Yewa River which separates Ajilete and Oke-Odan, all these town falls under Yewa South Local Government Area and are within a stretch of $8.12 \mathrm{~km}$ apart. Owode is one of the major towns in Yewa South Local Government Area and it is a nodal town located at the junction of Ado-Odo- Ilaro Road, and Sango-Idiroko Road, which leads to Benin Republic. Idiroko and ifonyintedo are under Ipokia Local Government Area and shares an international boundary with Benin Republic. However, Owode and Idiroko could be regarded as peri-urban Towns while Ajilete, Oke-Odan and Ifonyintedo basically are rural communities.

\section{Geology, Relief, Drainage and Soils}

The geology of Ogun State is made up of two main rock types: The basement complex rock of the pre-cambian age which are made up of the older and younger granites in the northern part of the State. It is essentially non porous and water are only found in the crevices and fissures of this consolidated rock formation. This basement complex primarily underlies the sedimentary layers which consist of cretaceous, tertiary and quaternary sediments deposited in the coastal basin. The younger and older sedimentary rock of both the tertiary and secondary age of this southern part is under coastal plain formation. The topography of the study area is characterized by a wide area of undulating lowland belonging to the coastal sedimentary rock of western Nigeria.

With the general topography in the state sloping from North to the South, the implication of majority of the river that traverse in the State that flows southwards either as tributaries joints of the main rivers that flow into the coastal lagoons and the Atlantic Ocean. These include Yewa, Ohu, Abafon, Oyan, Iju, Awuko, Iseje, Ojumo and others. The study area is well drained by these stream and rivers, much of which dry up during the dry season.

The soils in the study area are derived from sedimentary rocks in the southern part of the state which are varied in the components and texture. Soils in the south-western part of the state and most of the western part are sandy and could only support savanna vegetation which is suitable for cattle rearing. The river valleys have alluvial soils. 


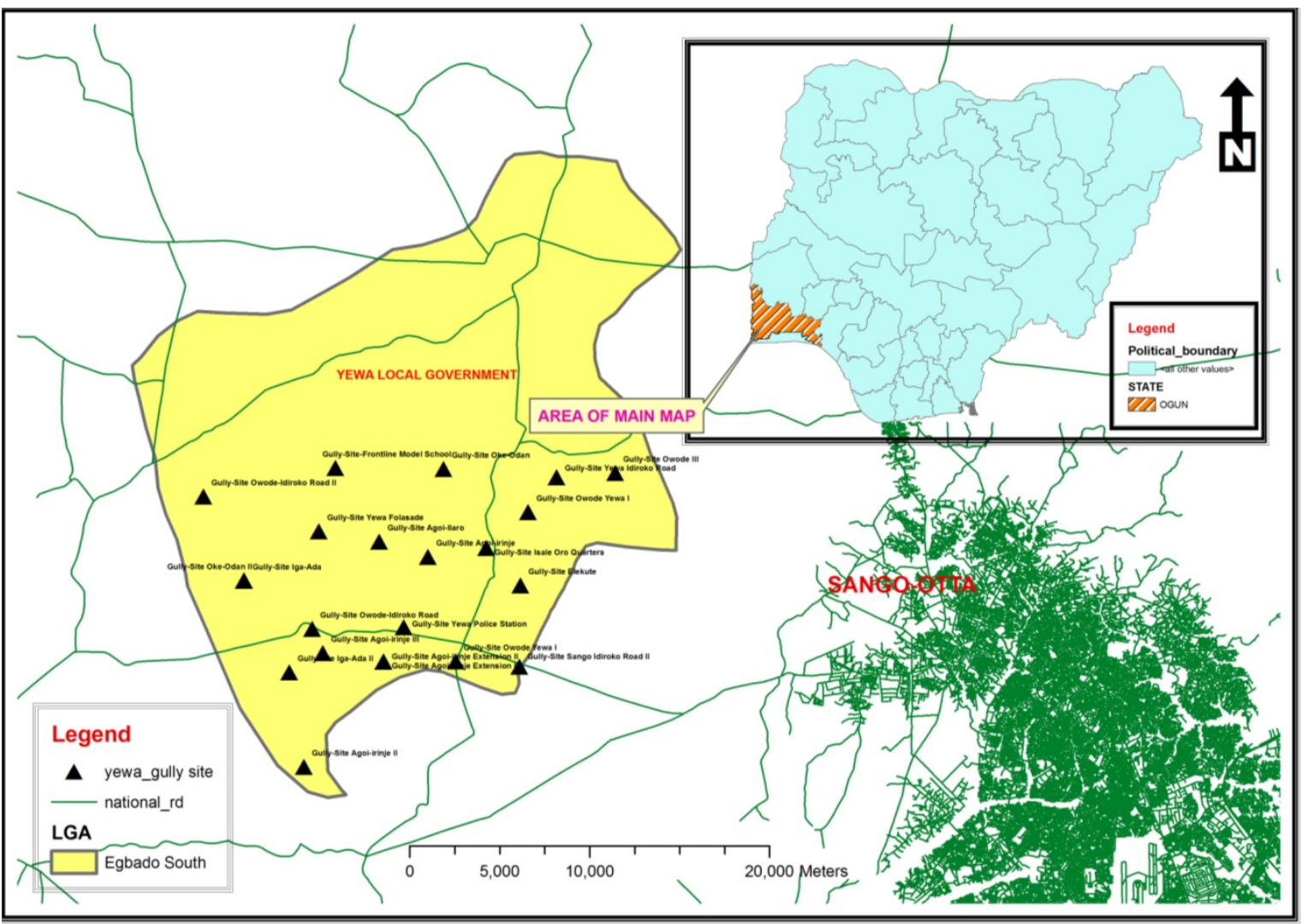

Figure 1. Map of Yewa South LGA showing the Study sites

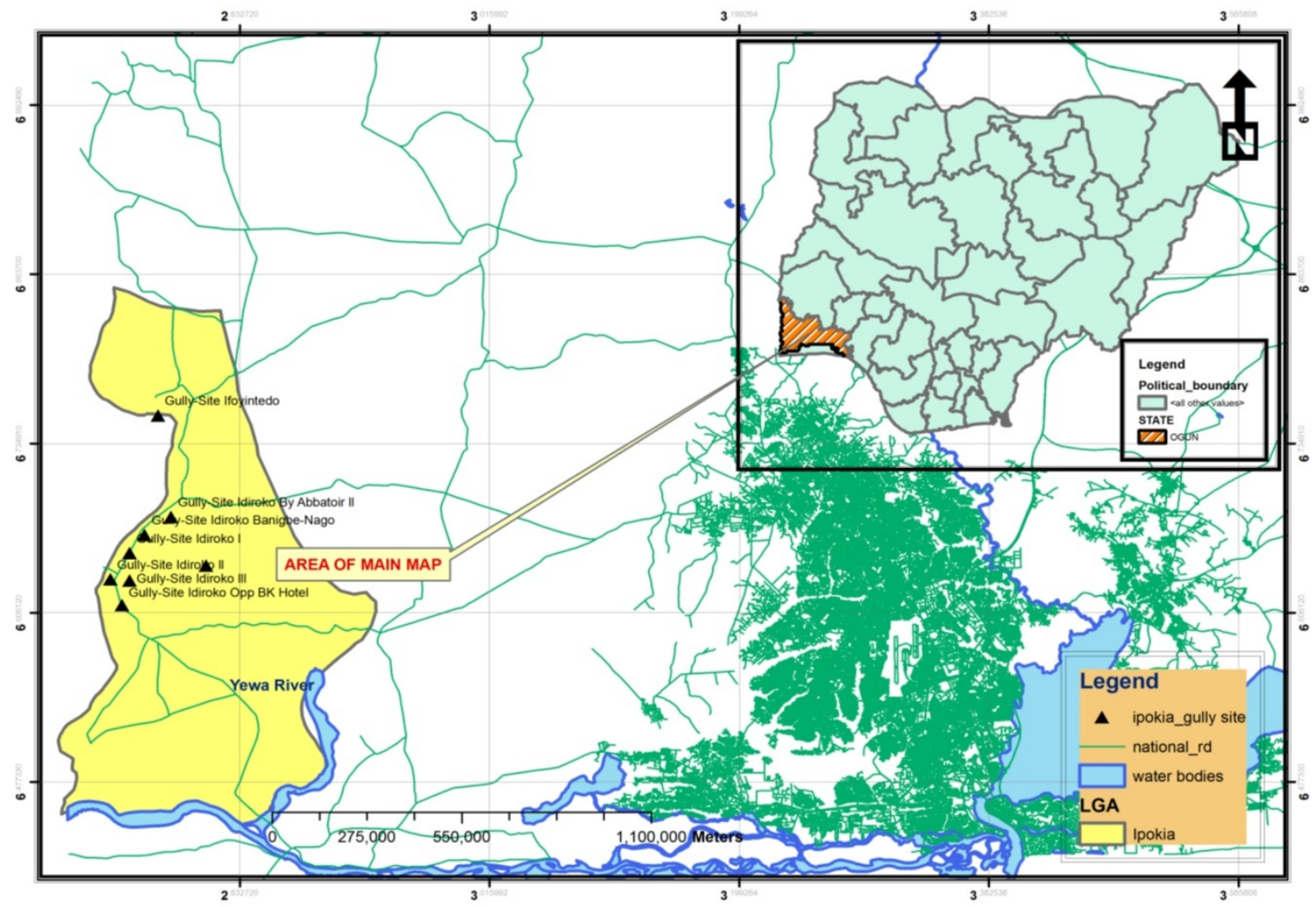

Figure 2. Map of Ipokia LGA showing the study sites 


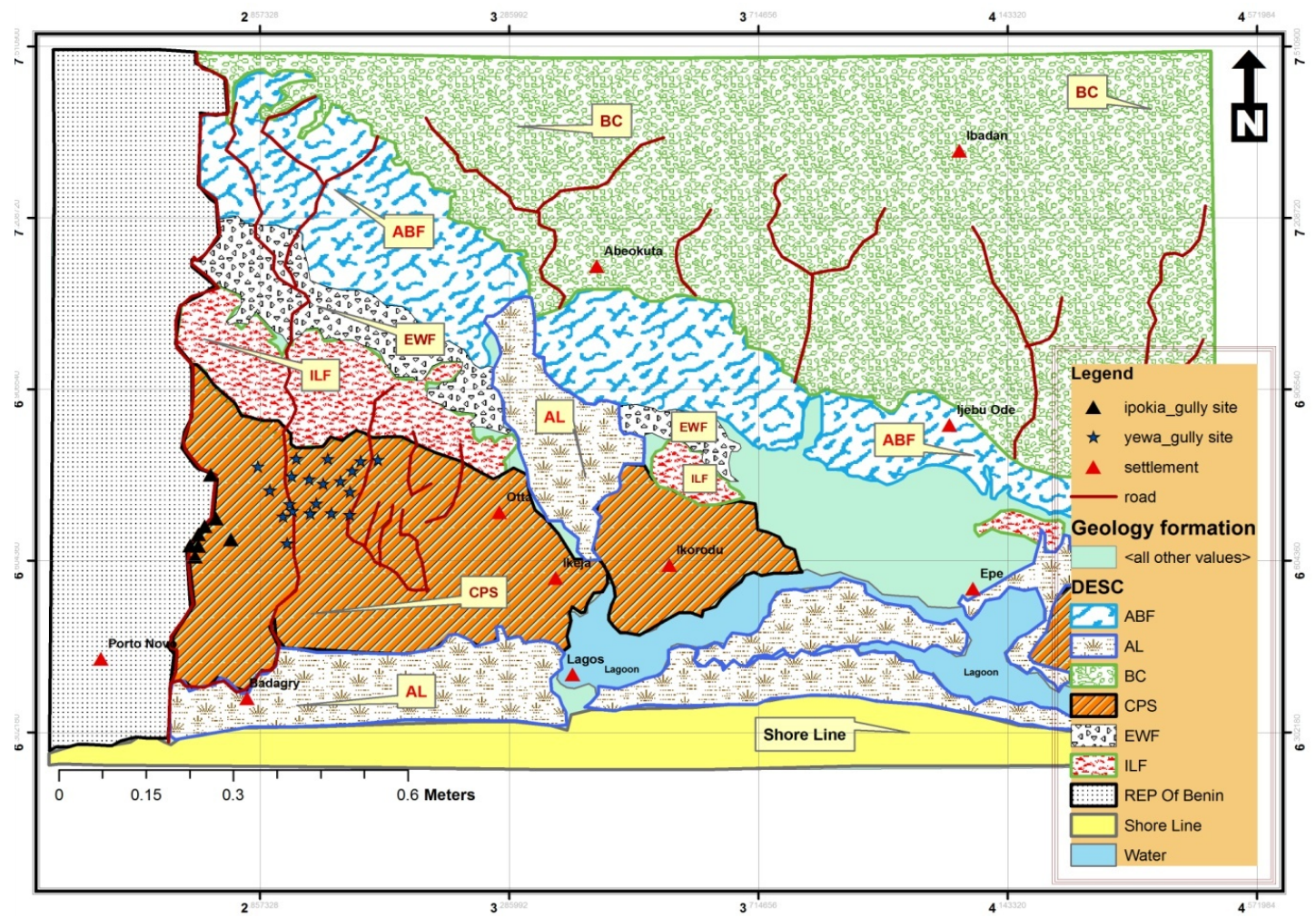

Figure 3. Geology map of Ogun State showing the Gully Site

Source: Federal Survey, 1963

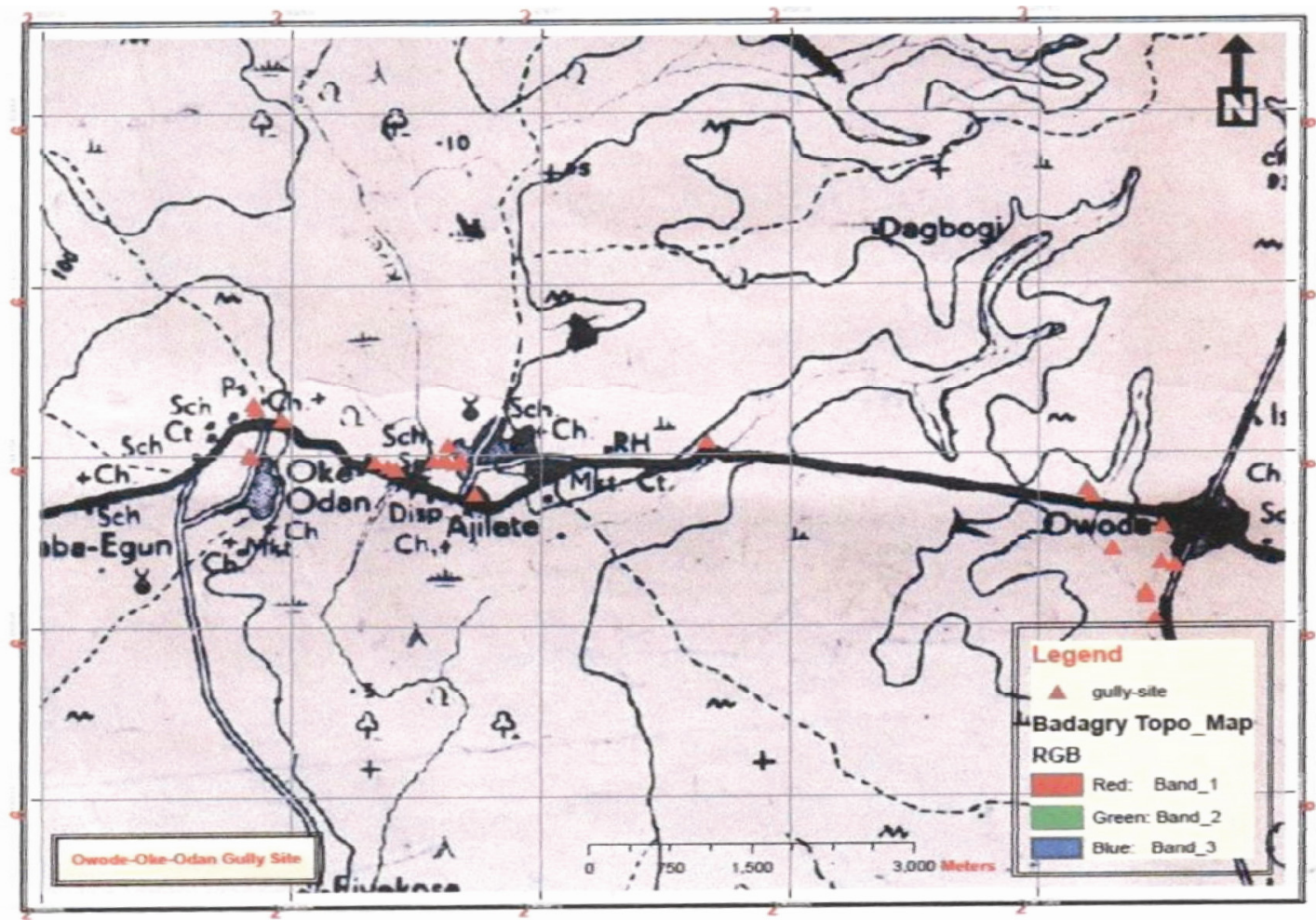

Figure 4a. Topographical map of the study area showing the Owode-Oke-Odan Gully Sites Sources: Federal Survey, 1963 


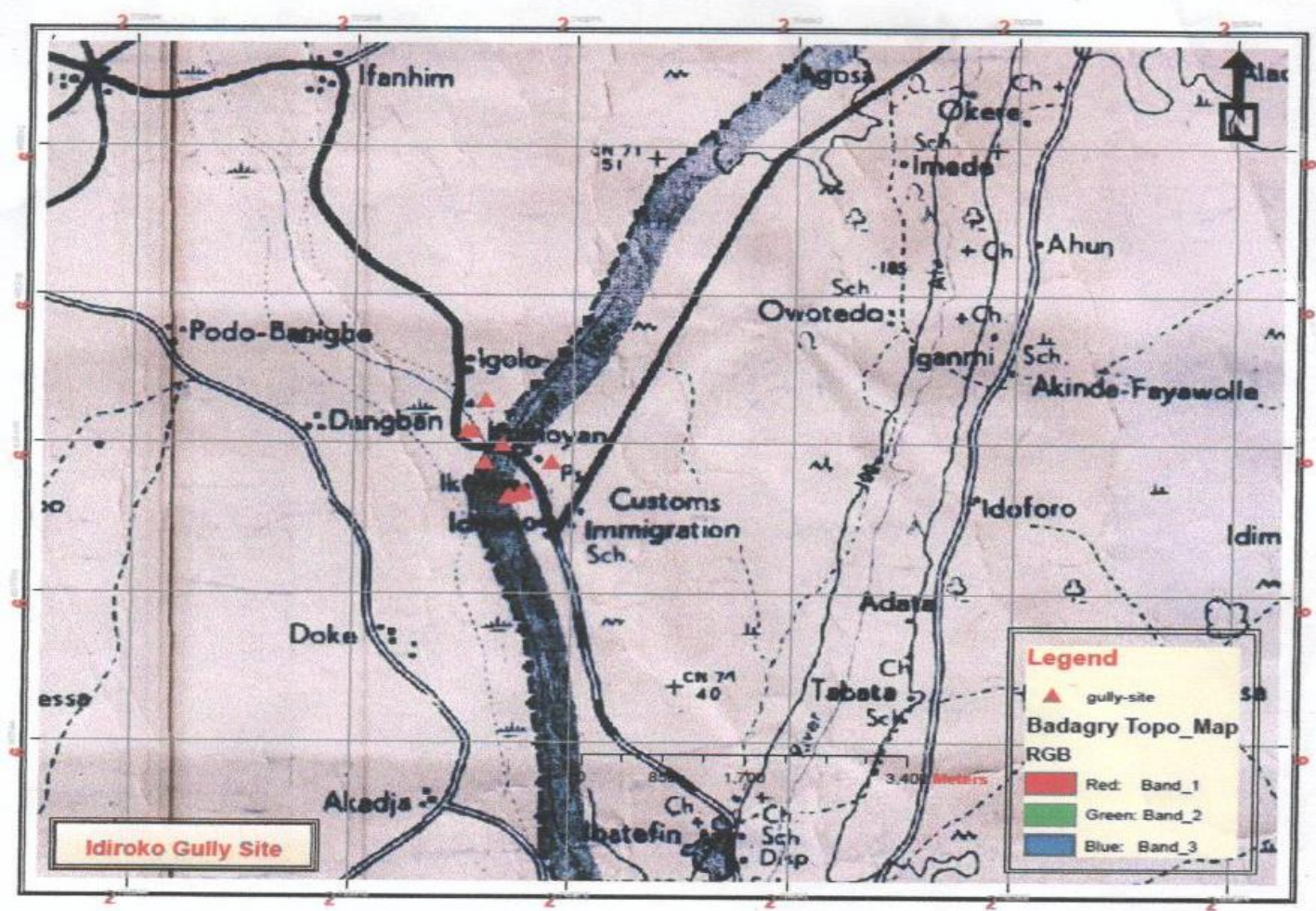

Figure 4b. Topographical map of the study area showing the Idiroko Gully Sites Sources: Federal Survey, 1963

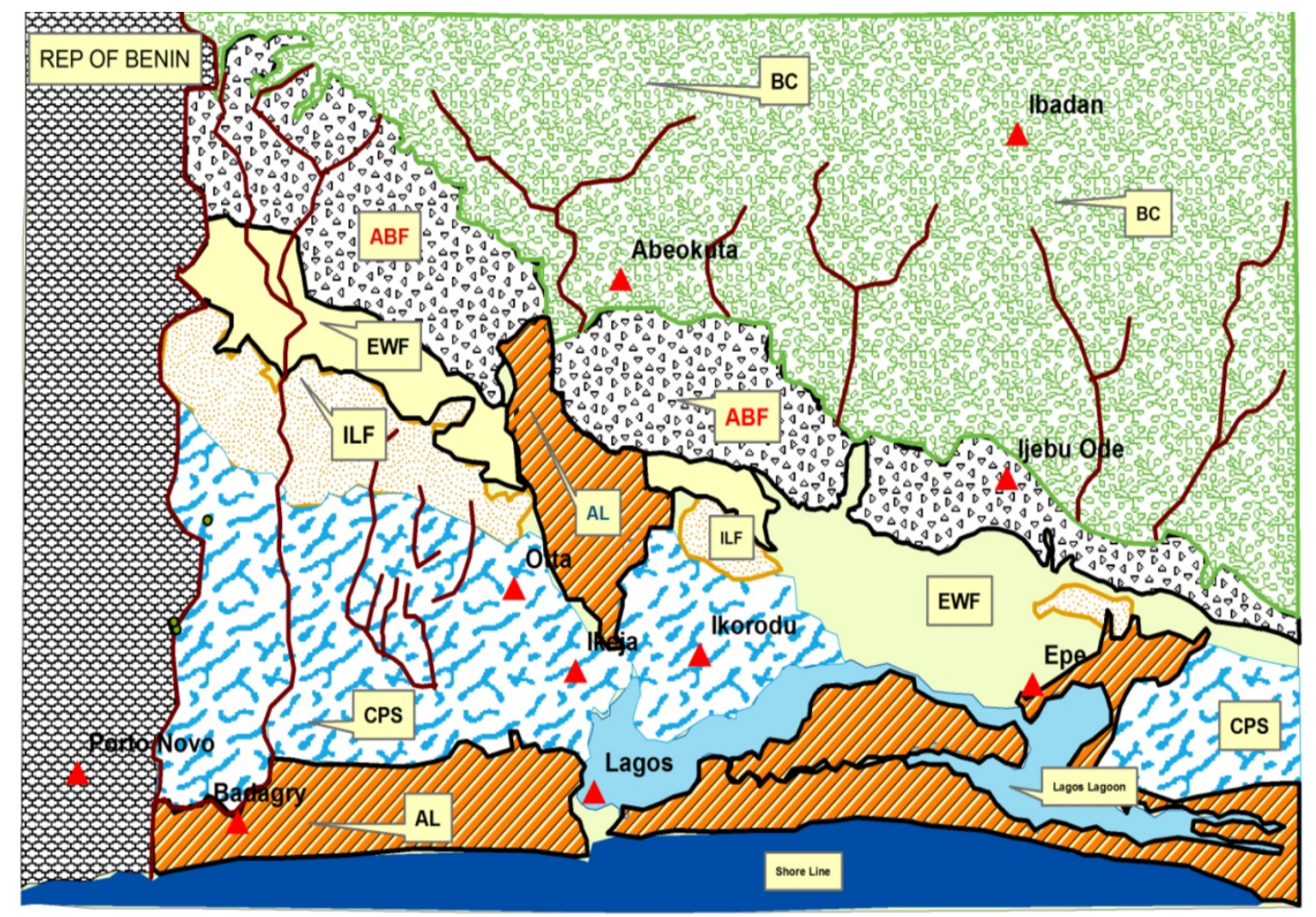

Figure 5. Map of the Ogun State showing rock formation CPS - Coastal Plain Formation 


\section{The Data Acquisition Process and Sampling Procedure}

The gully systems and the form parameters represent the total population of the study. This covers gullies of different sizes and a total of one hundred and twenty gullies were identified through the use of satellite images and direct ground observations. Among these, thirty-two gullies of different sizes were selected from the population using randomized sampling techniques. The parameters chosen for the study include shoulder width/depth ratio, shoulder width/bed width ratio and cross sectional area.

Data on the morphometric parameters of the gullies were collected through direct field measurements. These are depth, shoulder width, bed width and cross sectional areas. The shoulder width/depth ratio, and shoulder width/bed width ratio were calculated in the office.

Data which involved measuring the distance from gully head to its tails e.g. gully length were measured at intervals where the gully cross sections changed abruptly. The slope angles were measured using Rainfall and temperature data were obtained from the nearest metrological station at Abeokuta in Ogun State.

The data obtained from the fieldwork were analyzed by using descriptive and inferential statistics. Descriptive statistics used are the mean, standard deviation, and variance. Since the samples chosen was not really large $(<30)$, the skewness and kurtosis were considered unreliable estimators. However, in certain cases observations were made on the skewness and kurtosis where found necessary. The Pearson's product moment correlation technique was employed to examine the nature of the interrelationships between the morphometric properties of the gullies. It was reasonable to select the mean value of all the gully parameters for the correlation matrix as this still represents the general pattern. A correlation matrix showing the inter correlation among the eight gully parameters was also computed and tested for significant at 0.05 and 0.01 level for the study area.

\section{Results and Discussion}

\subsection{Characteristics of Gullies in Yewa South and Ipokia}

The gullies in the study area range from relatively long to short length gullies, measuring about $207.3 \mathrm{~m}$ as the longest and $20.6 \mathrm{~m}$ as the shortest. The depth varies between $2.47 \mathrm{~m}$ at some point toward its head to under $0.2 \mathrm{~m}$ at its mouth and the maximum mean gully depth was recorded as $1.77 \mathrm{~m}$ while the minimum was recorded as $0.24 \mathrm{~m}$. However, no definite patterns to depth decrease or increase towards a particular direction was observed. The study reveals that some of the shallow and deep sections of the gullies may be attributable to local factors along the gullies courses (Figures 6-7).

The gullies have a fairly straight course with the exception of few ones and the mean straight line distance between the gully head and mouth is about $302 \mathrm{~m}$. The mean shoulder width and bed width parameters range between $4.42 \mathrm{~m}$ and $2.38 \mathrm{~m}$ as maximum at one point to $0.6 \mathrm{~m}$ and $0.17 \mathrm{~m}$ as minimum in some other point. Ironically, the bed widths in all the gullies are narrower than the shoulder width, this implies that the gullies are wider at shoulder level and taper downward. As regards the general configuration, it was observed that some of the gullies are U-shaped with wide bed and vertical wall side, while the rest are V-shaped with the side taper and sloping downward and Trapezoidal-shaped in nature. The results of the descriptive statistics are shown in the summary table below.

Table 1. The results of the descriptive statistics of Gully Parameters (Source: Fieldwork, July, 2011)

\begin{tabular}{lllllllll}
\hline Gully Parameters & N & Range & Sum & Mean & Std.Dev. & Variance & Skewness & Kurtosis \\
\hline Gully Bed Width & 32 & 20.5 & 206.5 & 6.45 & 4.21 & 17.7 & 1.78 & 4.48 \\
Shoulder Width & 32 & 36.03 & 352.20 & 11.01 & 7.82 & 61.12 & 2.09 & 5.11 \\
Gully Depth & 32 & 16.28 & 136.32 & 4.26 & 3.51 & 12.66 & 2.01 & 5.19 \\
Gully Length & 32 & 186.7 & 2530.1 & 79.10 & 40.97 & 1679.01 & 1.24 & 2.04 \\
Shoulder Width/Depth Ratio & 32 & 64.77 & 716.55 & 22.40 & 14.00 & 196.05 & 1.73 & 3.80 \\
Shoulder Width/ Bed Width Ratio & 32 & 20.10 & 387.66 & 12.12 & 4.84 & 23.44 & 1.09 & 1.20 \\
Slope Angle & 32 & 17.80 & 504.60 & 15.77 & 4.95 & 24.55 & 0.25 & -0.72 \\
Cross Sectional Area & 32 & 72.91 & 322.73 & 10.09 & 15.37 & 236.35 & 3.30 & 11.34 \\
\hline
\end{tabular}



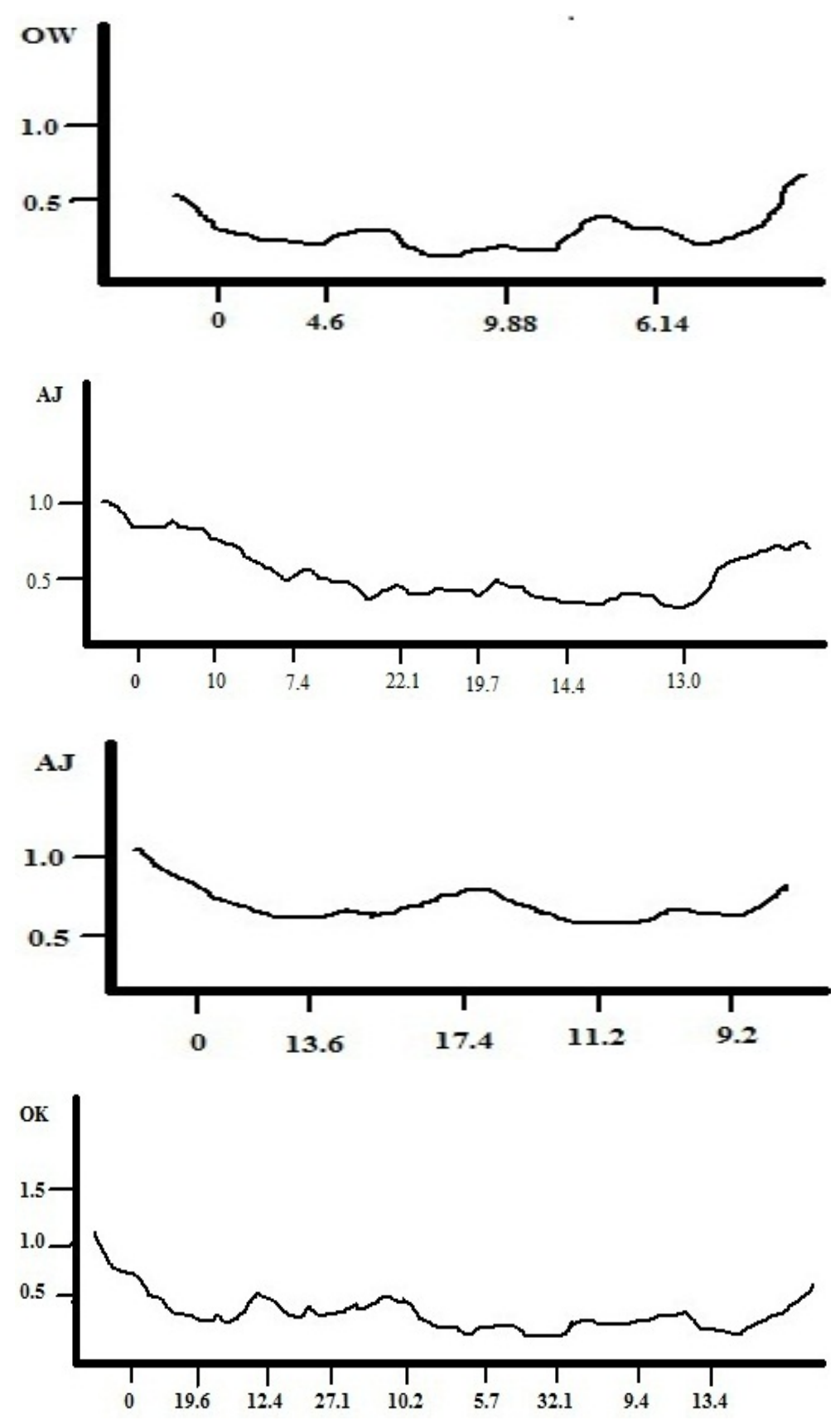

Figure 6. Cross profile of Yewa South and Ipokia Gullies Source: Based on Field Survey (July, 2011) 

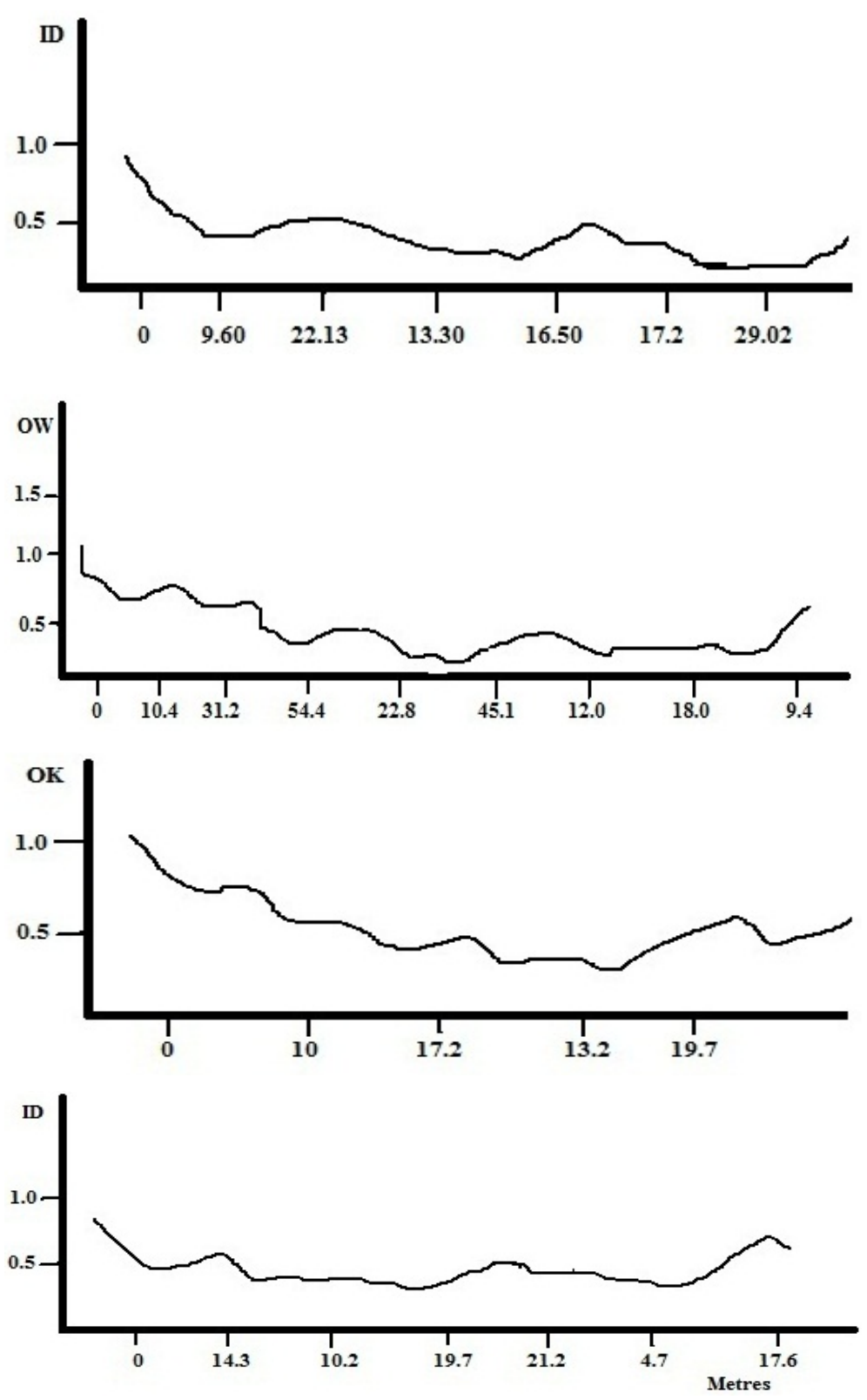

Figure 7. Cross profile of Yewa South and Ipokia Gullies

Source: Based on Field Survey (July, 2011)

\subsubsection{Gully Bed width}

The result of the data analyzed indicate that bed width parameter range between minimum of $.69 \mathrm{~m}$ at same point to about $21.21 \mathrm{~m}$ as maximum in other point with mean value of $6.45 \mathrm{~m}$. Indication from the table reveals that the bed widths in all the gullies are narrower than the shoulder width. In terms of dispersion it has a standard deviation of $4.20 \mathrm{~m}$ which shows high value of dispersion with relative variability of $65.11 \%$.

\subsubsection{Gully Length}

Gullies in the study area varies in terms of length indicated by the data obtained which range between $20.60 \mathrm{~m}$ to about $207.30 \mathrm{~m}$ long, with a mean gully length of $79.06 \mathrm{~m}$. However, some of the gullies are relatively short as indicated by the data obtained in the field. In term of relative variability the gully length shows moderate variability with coefficient of variation of $51.82 \%$ with highest value of dispersion with standard deviation of $40.97 \mathrm{~m}$. These gullies therefore have a fairly straight course with exceptional cases of few meandering, it is observed that the gully length have a flat top near the mean with low kurtosis of $2.4 \mathrm{~m}$ and the gully length is 
positively skewed.

\subsubsection{Shoulder Width}

The outcome of the data indicate that the shoulder width parameter values varies between the minimum of 2.87 $\mathrm{m}$ at a point to about $38.90 \mathrm{~m}$ as maximum in other point with a dispersion rate of $7.81 \mathrm{~m}$ while the table reveals mean value of $11.00 \mathrm{~m}$. The variation is very high with coefficient of variation of $71 \%$. The result shows that most of the gullies are wider at shoulder level and taper downward indicating a $\mathrm{V}$ slope valley.

\subsubsection{Gully Depth}

As reveals by the table the gully depth values range between $0.80 \mathrm{~m}$ as minimum at one point to $17.08 \mathrm{~m}$ as maximum at another point, the mean gully depth values is around $4.26 \mathrm{~m}$ and the table shown that gully depth has the least dispersion with standard deviation of $3.50 \mathrm{~m}$ and coefficient of variation of $82.16 \%$ this however indicate high variability.

However, it was observed that there are no definite patterns of gully depth increase or decrease toward a particular direction while deep sections were also noticed in some cases in the gullies. Moreover, the shallow and deep sections noticed in some sections of the gullies are due to some local factors along the course.

\subsubsection{Shoulder Width/Bed Width Ratio and Shoulder Width/Depth Ratio}

The table indicates that shoulder width/bed width ratio and shoulder width/depth ratio have gully parameters which vary between the range of $6.11 \mathrm{~m}$ and $7.07 \mathrm{~m}$ minimum at one point to $26.20 \mathrm{~m}$ and $71.84 \mathrm{~m}$ at the other point as maximum in the distribution with total mean value of $12.11 \mathrm{~m}$ and $22.4 \mathrm{~m}$ respectively. However, the table reveals that shoulder/bed width ratio has one of the least value of dispersion $(4.84 \mathrm{~m})$ in the distribution while shoulder width/depth ratio indicate high value of dispersion with $14.00 \mathrm{~m}$. By implication, shoulder width/depth ratio of coefficient and 39.96\% coefficient variation of shoulder width/bed width ratio show low variability in the distribution. However, it is important to stress that high mean value of shoulder width/bed width ratio denote $\mathrm{V}$-shaped gully channels.

\subsubsection{Slope Angle}

It is evident from the table that the slope gradient in which the gullies develops ranges between $7.4^{\circ}$ at one point to $25.3^{\circ}$ at other point with a mean value of $15.76^{\circ}$. In the distribution, the gradient is the least variability with coefficient variation of $31.52^{\circ}$ and standard deviation of $4.95^{\circ}$ in term of peaked of flat relative to a normal distribution which show a smallest possible value of kurtosis which is $-0.72^{\circ}$ while the gradient has a skewness of $0.25^{\circ}$ which indicate that values are relatively evenly distributed in both side of the mean.

It is revealed from the table that the parametric value of the cross sectional area range from $63 \mathrm{~m}$ minimum to $73.54 \mathrm{~m}$ showing the maximum point with a mean value of $10.08 \mathrm{~m}$. Going further, the table reveal that the cross sectional area has the most variability characteristic value in the distribution with $152.5 \%$ coefficient of variation and the standard deviation indicates that a high dispersion value with $15.37 \mathrm{~m}$.

\subsection{Relationships among the Gully Parameters}

The result of the simple Pearson's product moment of the gully parameters is presented in the table 4.2 below. The table reveals that most of the gully morphometric parameters vary together in the same direction. However, indications from the table show that of the 28 correlation coefficient, 18 were significant at 0.05 significance level representing $64.3 \%$, while $25 \%$ of the total correlations were not significant and only $10.7 \%$ were significant at 0.01 significance levels. This result is similar to the one obtained by Ebisemiju (1989) and Udosen (1991) which affirm that $60 \%$ and $60.7 \%$ respectively of the gully parameters were significantly correlated. This confirms the existence of steady state adjustment between the form parameters of the gullies was confirmed.

It is evident from table that the correlation between the slope angle and other gully parameters were strong and significant at 0.05 level of significance with the exception of shoulder width/depth ratio $(0.381)$ which is weak and not significant. This result is almost similar to the one obtained by Jeje (1978), he obliged that slope inclination appear to be subordinate to factors of vegetal cover, soil erodibility and rainfall erosivity. Moreover, there could be reduction in the effect of slope on gully development when erosivity and erodibility is also lacking and vegetal cover strong. 
Table 2. Correlation Table Showing Relationship among Gully Parameters

\begin{tabular}{|c|c|c|c|c|c|c|c|c|c|}
\hline & & $\begin{array}{l}\text { Gully } \\
\text { Length }\end{array}$ & $\begin{array}{l}\text { Bed } \\
\text { Width }\end{array}$ & $\begin{array}{l}\text { Shoulder } \\
\text { Width }\end{array}$ & $\begin{array}{l}\text { Gully } \\
\text { Depth }\end{array}$ & $\begin{array}{l}\text { Slope } \\
\text { Angle }\end{array}$ & $\begin{array}{l}\text { Shoulder } \\
\text { Width/Bed } \\
\text { Width }\end{array}$ & $\begin{array}{l}\text { Shoulder } \\
\text { Width/Depth }\end{array}$ & $\begin{array}{l}\text { Gully Cross } \\
\text { Sectional Area }\end{array}$ \\
\hline \multirow{3}{*}{$\begin{array}{l}\text { Gully } \\
\text { Length }\end{array}$} & Pearson Correlation & 1 & $.572^{* *}$ & $.645^{* *}$ & $.460^{* *}$ & $.817^{* *}$ & $.662^{* *}$ & $.604^{* *}$ & $.400^{*}$ \\
\hline & Sig. (2-tailed) & & .001 & .000 & .008 & .000 & .000 & .000 & .023 \\
\hline & $\mathrm{N}$ & 32 & 32 & 32 & 32 & 32 & 32 & 32 & 32 \\
\hline \multirow{3}{*}{$\begin{array}{l}\text { Bed } \\
\text { Width }\end{array}$} & Pearson Correlation & $.572^{* *}$ & 1 & $.951^{* *}$ & $.863^{* *}$ & $.611^{* *}$ & .268 & .171 & $.876^{* *}$ \\
\hline & Sig. (2-tailed) & .001 & & .000 & .000 & .000 & .139 & .349 & .000 \\
\hline & $\mathrm{N}$ & 32 & 32 & 32 & 32 & 32 & 32 & 32 & 32 \\
\hline \multirow{3}{*}{$\begin{array}{l}\text { Shoulder } \\
\text { Width }\end{array}$} & Pearson Correlation & $.645^{* *}$ & $.951^{* *}$ & 1 & $.899^{* *}$ & $.655^{* *}$ & $.491^{* *}$ & .147 & $.910^{* *}$ \\
\hline & Sig. (2-tailed) & .000 & .000 & & .000 & .000 & .004 & .423 & .000 \\
\hline & $\mathrm{N}$ & 32 & 32 & 32 & 32 & 32 & 32 & 32 & 32 \\
\hline \multirow{3}{*}{$\begin{array}{l}\text { Gully } \\
\text { Depth }\end{array}$} & Pearson Correlation & $.460^{* *}$ & $.863^{* *}$ & $.899^{* *}$ & 1 & $.617^{* *}$ & $.434^{*}$ & -.177 & $.924^{* *}$ \\
\hline & Sig. (2-tailed) & .008 & .000 & .000 & & .000 & .013 & .331 & .000 \\
\hline & $\mathrm{N}$ & 32 & 32 & 32 & 32 & 32 & 32 & 32 & 32 \\
\hline \multirow{3}{*}{$\begin{array}{l}\text { Slope } \\
\text { Angle }\end{array}$} & Pearson Correlation & $.817^{* *}$ & $.611^{* *}$ & $.655^{* *}$ & $.617^{* *}$ & 1 & $.623^{* *}$ & $.381^{*}$ & $.484^{* *}$ \\
\hline & Sig. (2-tailed) & .000 & .000 & .000 & .000 & & .000 & .032 & .005 \\
\hline & $\mathrm{N}$ & 32 & 32 & 32 & 32 & 32 & 32 & 32 & 32 \\
\hline \multirow{3}{*}{$\begin{array}{l}\text { Shoulder } \\
\text { Width/Bed } \\
\text { Width }\end{array}$} & Pearson Correlation & $.662^{* *}$ & .268 & $.491^{* *}$ & $.434^{*}$ & $.623^{* *}$ & 1 & .225 & .314 \\
\hline & Sig. (2-tailed) & .000 & .139 & .004 & .013 & .000 & & .216 & .080 \\
\hline & $\mathrm{N}$ & 32 & 32 & 32 & 32 & 32 & 32 & 32 & 32 \\
\hline \multirow{3}{*}{$\begin{array}{l}\text { Shoulder } \\
\text { Width/Depth }\end{array}$} & Pearson Correlation & $.604^{* *}$ & .171 & .147 & -.177 & $.381^{*}$ & .225 & 1 & -.080 \\
\hline & Sig. (2-tailed) & .000 & .349 & .423 & .331 & .032 & .216 & & .664 \\
\hline & $\mathrm{N}$ & 32 & 32 & 32 & 32 & 32 & 32 & 32 & 32 \\
\hline \multirow{3}{*}{$\begin{array}{l}\text { Gully Cross } \\
\text { Sectional } \\
\text { Area }\end{array}$} & Pearson Correlation & $.400^{*}$ & $.876^{* *}$ & $.910^{* *}$ & $.924^{* *}$ & $.484^{* *}$ & .314 & -.080 & 1 \\
\hline & Sig. (2-tailed) & .023 & .000 & .000 & .000 & .005 & .080 & .664 & \\
\hline & $\mathrm{N}$ & 32 & 32 & 32 & 32 & 32 & 32 & 32 & 32 \\
\hline
\end{tabular}

*: Correlation is significant at the 0.05 level (2-tailed).

**: Correlation is significant at the 0.01 level (2-tailed).

Furthermore, Shoulder-width/ depth ratio has an inverse correlation with Cross Sectional Area (-0.080) and gully depth (-0.177). The table reveals that other gullies parameters have weak correlation with shoulder-width/depth ratio with exception of Gully length (0.604). Indication from the table shows that correlation between shoulder-width and gully depth is highly envisage as it is significant at 0.05 level of significance. This indicates that the rate of side retreat is proportional to the rate of gully deepening. Aside from this, there is strong correlation between shoulder-width and bed-width (0.95) and this implies that the rate of gully side retreat is proportional to marginal increase of the bed-width. This value is significant at 0.05 level of significance.

Another strong correlation in the table is between bed-width and cross sectional area (0.88), this shows that bed-width increase marginally with cross sectional area while there is a poor correlation between the bed-width and shoulder-width/bed-width ratio (0.27) and shoulder-width/depth ratio (0.17). In the same vein, there is a strong correlation among the gully head, shoulder-width and bed-width, this indicate that there is a proportional increase in the size of shoulder and bed-width as the length of the gully increased. Observation from the table reveals that there is a strong correlation between the gully depth and bed-width (0.86). The implication of this is that, as the gully depth increases, bed-width also tends to vary in the same direction.

Furthermore, it is observed that there is a strong correlation between gully depth and cross sectional area, 0.92 of the variation in cross sectional area is provided by gully depth and this value is significant at 0.05 significance levels. These analyses indicate complex relationships between the form elements of the gully system. However, 
it should be noted that correlation does not necessarily means causality. High correlation may indicate cause and effect, it might show mutual interaction of two variables or it could reflect the influence of a third factor controlling the two variables. Invariably low correlation does not imply there is no relationship rather there may be no or little cause and effect relationship.

Lastly, the stage of gully development and processes operating on gully sides, bottom and head, the character of the bed rock, rainfall and the effect of human actions and his animals on gully banks may also affect the nature of the interrelationships among the gully parameters.

\section{Conclusions and Recommendations}

The present and past gullying process in Yewa South and Ipokia were related to environmental changes that induce surface and subsurface runoff from the slope to the valley bottom. The study has place emphasis on form-form interrelationship of gully elements in the area. Those gullies studied are simple in plan with more or less direct courses. Most of these gullies appeared to have developed along an abandoned footpath, streets and usually through poor cultivation methods often involving heap making, circular mounds on gentle slope and alignment of ridges orthogonally to the slopes initiate gullies in the area.

The result obtained in the studied area are in conformity with Ofomata (1965) and Ologe (1972) view that bare surface and local hydrological characteristics are partly responsible for gullying all over Nigeria which was collaborated as increase from gully head had proportional increase of lateral recession. It was also ascertained in the area that relationship between slope angle and distance from gully head is significant at 0.05 level which conformed with findings in other studies. Lar (1976) noted that under natural slope erosion increases with increase in on slope angle. Jeje (1978) stressed that the degree of sloping appears to be subordinate to factors of vegetation cover, soil and rainfall factors. In line with Ebisemiju (1989), findings on gully side retreat, we conclude that lateral erosion is proportional to the rate of gully deepening. This holds in the study area where shoulder-width and gully depth shows strong relationship that is significant at 0.05 levels.

Furthermore, the high positive correlation between shoulder-width and bed-width, indicate form-form adjustment rather than cause and effect relationship. Both variables are dependent on other controlling factors including nature of bed and bank materials, human influence and runoff characteristic. Also gully sizes (length) do not affect the total gully area directly. Gully area is affected more by depth, and width variables, hence the weak correlation between distance from gully head and cross sectional area. Climatically, the available data on rainfall and temperature indicates a higher annual average rainfall. The extent to which this affected gully development was not measured directly. We also found that intensive continuous cropping of agricultural farming system over the years resulted in the exposure of soil to surface erosion agents and may have also aided the rate of gully development.

In areas that are susceptible to soil erosion like this one, there is need for proper monitoring and comprehensive conservation strategies and control measures. In order to achieve the ultimate aim of which is proper soil management, there is need to encourage bio-environmental process in the area. Planting of single-tree specie in most cases has not been effective in controlling soil erosion problem. Hence, it is recommended that planting of different species of trees when using tree planting as a control measure for restoring eroded soil is highly necessary.

It is equally important to review relevant environmental laws and policies to make them suitable for the prevention of anticipated soil erosion problem in the area. This would help to enforce compliance of Environmental Impact Assessment law (EIA) in the area; especially those involves in constructional activities.

\section{References}

Areola, O. (1990). The Good Earth. Inaugural Lecture delivered at the University of Ibadan. pp 17-22.

Areola, O., \& Faniran, A. (1994). Landform examples from Nigeria: A Gully. The Nigeria Geographical Journal, 17(1), 57-60

Ebisemiju, F. S. (1979). Gullies in Guyana: A Quantitative Analysis of Morphometric Properties. Savanna, 8, 19-39.

Ebisemiju, F. S. (1989). A Morphometric approach to gully analysis. Geomorphologies, 33(3), 307-322.

Faniran, A. A., \& Areola, O. (1978). Essential of Soil Study. Ibadan: Heinemann, pp 212.

Haggitt, D. C. (1991). Soil Erosion and Soil Problem in progress. Physical Geography, 15(1), 91-100. http://dx.doi.org/10.1177/030913339101500108 
Harvey, A. (1982). The role of piping in the development of badlands and gully systems in south-east Spain. Bad Lands Geomorphology and Piping, 317-335.

Heede, B. J. (1974). Stages of Development of Gullies in Western USA. Geomorphologies, 18, 260-273.

Jeje, L. K. (1973). Erosion along Ife-Ondo Road in Western Nigeria. Nigerian Geographical Journal, 16(1), 67-72.

Jeje, L. K. (1978). A Preliminary Investigation into Soil Erosion on Cultivated Hill sides in parts of Western Nigeria. Geographical Ecology Tropic, 2(2), 175-187.

Jeje, L. K. (1982). Accelerated Soil Erosion in Araromi Rubber Plantation, Ondo State. Ife Journal of Africulture, 4.

Jeje, L. K. (1983). Aspect of Geomorphology of Nigeria. In A Geography of Nigeria Development, Oguntoyinbo J. S. et al. (ed). HEB Ibadan, pp 55-89.

Jeje, L. K. (1991). Urbanization and Accelerated Erosion: The Case of Effon Alaaye in Ondo State. Paper Presented at the 3rd annual seminar of NGWG at Bendel State University, Ekpoma 12th April

Lar, R. (1976). Soil Erosion Problems on Altisols in Western Nigeri and their Control. Ibadan: IITA Monograph I IITA, pp 1-5.

Ofomata, G. E. K. (1965). Factors of Soil Erosion in the Enugu State of Nigeria. Nigerian Geographical Journal, 8(1), 33-34.

Ofomata, G. E. K. (1973). Aspect of Geomorphology of the Nsukka-Okogwe Cuesta, East Central state of Nigeria. Bulleting de FAN. 33, Seme A.U. 59 -80

Ofomata, G. E. K. (1978). Man as a Factor of Soil Erosion in South Eastern Nigeria. Geo-Eco Trop., 2(2), 143-154.

Ologe, K. O. (1972). Gullies in the Zang Area: A preliminary Study of HeadScarp Recession. Savanna, 1(1), 55-56.

Ologe, K. O. (1974). Kudingi Gully: Headscarp Recession. Savanna, 1(1), 87-90.

Ologe, K. O. (1988). Soil Erosion Characteristics, Processes and the extent in the Savanna and Sahel region. In Ecological Disaster in Nigeria Enabor, E. E. et al. (eds.). Lagos: Soil Erosion, Federal Ministry of Science and Technology, pp 26-49.

Udosen, C. E. (1991). A Morphometric Analysis of Gullies in Obotme Area of Akwa-Ibom State. MSc Thesis (Unpublished), University of Ibadan, Ibadan. pp 43-55.

Udosen, C. E. (2000). Threshold of Gully Erosion in the Coastal Plain Sand of Eastern Nigeria. An Unpublished Ph.D Thesis, University of Ibadan, Ibadan

Withlow, R. (1994). Gullying within Wetlands in Zimbabwe. Morphological Characteristic of Gullies. South African Geographical Journal, 76(1), 11-19. http://dx.doi.org/10.1080/03736245.1994.9713565 